\title{
Peluang Penerapan Teknologi Desalinasi Dalam Penyediaan Air Minum
}

\author{
Gede H. Cahyana
}

\begin{abstract}
Abstrak
Penyusutan debit air tawar menimbulkan ancaman bagi kelangsungan pasokan air minum. Agar tidak merugikan kehidupan manusia, perlu diterapkan teknologi yang mampu mengolah air laut atau air payau yang jumlahnya sangat banyak. Salah satu teknologi desalinasi ialah teknologi membran. Membran memang dikembangkan untuk maksud tersebut, namun harganya masih sangat mahal sehingga di Indonesia belum banyak yang menerapkannya. Selain membran, teknologi penguapan juga menjadi alternatif dalam penyediaan air minum, misalnya distillasi sekejap multitahap. Apabila harganya bisa relatif lebih murah, maka peluang penerapannya menjadi sangat luas dan memudahkan orang untuk memperoleh air minum, khususnya yang tinggal di pantai.
\end{abstract}

Kata kunci: air baku, pretreatment (praolah), desalinasi, membran

\section{Pendahuluan}

Bisa dikatakan, 100\% teknologi pengolahan air minum yang dimiliki PDAM hanyalah berupa teknologi konvensional, sebuah teknologi yang mulai berkembang sekitar 150 tahun yang lalu. Karena pencemaran air baku makin luas dan makin tinggi konsentrasi polutannya, maka teknologi konvensional tidak mampu menanganinya sehingga diperlukan tambahan teknologi yang lain. Oleh sebab itu, tidak semua PDAM memiliki kawasan yang kualitas airnya sudah layak diminum langsung (potable water) di krankrannya, khususnya dalam kompleks tertentu. Namun demikian, ada beberapa PDAM yang selangkah di depan (atau minimal sudah berencana membuat kawasan tersebut) karena di sebagian daerah layanannya, sebagai daerah percontohan, telah dilengkapi sarana potable water.

\section{Opsi Instalasi}

Rancangan pengolahan air yang tepat bergantung pada kualitas air baku dan kualitas air olahan yang diinginkan. Perbedaan kualitas inilah yang menentukan jenis unit operasi dan unit proses yang bakal diterapkan. Untuk suplai kawasan khusus, misalnya perumahan, industri, gedung perkantoran, terminal, bandara dan lain-lain, ada dua opsi (alternatif) sumber air yang mungkin, yaitu air baku (raw water) dari sungai, danau, waduk, atau laut dan "air baku" yang berasal dari air olahan (treated water) PDAM. 
Opsi pertama perlu instalasi baru berupa complete treatment di dekat badan air atau di dalam area kawasan dengan kapasitas minimal yang direncanakan, misalnya $50 \mathrm{l} / \mathrm{d}$. Debit yang diolah tentu harus lebih besar daripada $50 \mathrm{l} / \mathrm{d}$ untuk antisipasi kehilangan air, kebocoran, kebutuhan air di instalasi, dan air yang terbuang dalam pengolahan dengan teknologi membran. Perlu pula dipertimbangkan kebutuhan sepuluh tahun ke depan sebagai siaga perluasan kawasan. Kalau debit yang diolah $50 \mathrm{l} / \mathrm{d}$ maka debit potable water-nya menjadi di bawah $50 \mathrm{l} / \mathrm{d}$. (Besar-kecilnya debit produksi ini dipengaruhi oleh kualitas air kiriman dari reservoir PDAM dan kualitas membrannya. Kualitas membran ini beragam, ditentukan oleh tipe membran, yaitu selulose asetat, composite, polyamide, dll. dan jenis modulnya: tubular, spiral, hollow fiber, atau plate-frame).

Kalau opsi kedua yang dipilih, yaitu air bakunya berasal dari air olahan (treated water) IPAM PDAM, maka tahap awal pengolahannya (pretreatment) sudah dilaksanakan. Berikutnya ialah pengolahan air di kawasan tersebut, yaitu Instalasi Pengolahan Air Minum Internal (IPAMI). Lokasinya di dalam area kawasan dengan unit operasi dan proses yang ditujukan untuk mencapai potable water. Pada opsi kedua ini pun air yang dialirkan dari reservoir PDAM harus lebih besar daripada $50 \mathrm{l} / \mathrm{d}$. Debit kiriman yang dibutuhkan untuk memproduksi $50 \mathrm{l} / \mathrm{d}$ potable water ini pun bergantung pada kualitas air kiriman. Makin buruk kualitasnya, makin besar air limbah yang dihasilkannya (konsentrat, rejection, brine water di unit membran), selain untuk kebutuhan bebersih di instalasi dan keperluan domestik internal.

Misalkan yang dipilih adalah opsi kedua, yaitu membuat IPAMI di area kawasan. Opsi kedua ini pun memiliki dua opsi pola suplai. Yang pertama ialah pola suplai Point of Use (PoU, Titik Guna) dan yang kedua Point of Entry (PoE, Titik Masuk). Instalasi PoU dipasang tersebar di lokasi yang akan difasilitasi dengan air layak minum, misalnya di ruang tunggu, toilet (tapi tidak di kamar mandi, WC), semua ruang kantor atau administrasi, koridor, dapur, area parkir, dll. Di setiap titik layanan disediakan storage tank air layak minum yang diolah di beberapa tempat secara terpisah dengan kapasitas yang jauh lebih kecil daripada $50 \mathrm{l} / \mathrm{d}$. Dengan cara ini ada penghematan biaya investasi (capital), hemat biaya operasi-rawatnya karena tidak semua kapasitas $50 \mathrm{l} / \mathrm{d}$ itu diolah menjadi potable water kecuali kalau semua kapasitas itu hendak dijadikan potable water dan pemakaiannya diserahkan kepada pengelola kawasan dengan konsekuensi biaya investasi (capital), operasi-rawatnya menjadi mahal. 
Pola kedua, yaitu PoE memperlakukan air olahan PDAM sebesar $50 \mathrm{l} / \mathrm{d}$ sebagai air baku bagi IPAMI. Instalasi difungsikan sebagai pengolahan lanjut (advanced treatment) dengan tetap mengacu pada perbaikan kualitas sesuai dengan unit operasi dan proses yang dibutuhkan. Pada pola PoE ini, semua kapasitas $(50 \mathrm{l} / \mathrm{d})$ akan diolah menjadi potable water sehingga otomatis biayanya lebih mahal daripada pola PoU. Dalam pola ini pun air produksinya tidak akan mencapai $50 \mathrm{l} / \mathrm{d}$ tetapi kurang dari itu. Kuantitas potable water ini bergantung pada jenis dan kondisi membran yang digunakan, kondisi operasinya (flow control dan tekanan kerja), dan kualitas air kiriman (jenis dan konsentrasi polutan seperti kekeruhan, $\mathrm{Fe}, \mathrm{Mn}, \mathrm{Ca}, \mathrm{Mg}$, pestisida, nitrat, nitrit, bakteri, algae, virus, mineral lain, temperatur dan $\mathrm{pH})$.

\section{Opsi Unit Operasi - Proses}

Untuk menyusun diagram alir IPAMI kawasan, spektrum ukuran partikel yang ada di dalam air olahan PDAM sebesar $50 \mathrm{l} / \mathrm{d}$ itu sangat penting diketahui dan dipastikan (relatif) tidak fluktuatif. Karena dialirkan melalui pipa di bawah tanah maka potensi kebocorannya tetap harus dipertimbangkan dan akan berpengaruh pada debit dan kualitas air kiriman, sekaligus berpengaruh pada jenis unit operasi dan prosesnya.

Sebagai pertimbangan kontrol kualitas, jenis material yang mungkin masuk ke dalam pipa transmisi air olahan PDAM ke ground reservoir di IPAMI kawasan ialah coarse (gross) solid, suspended solid, koloid, dan dissolved solid. Dengan kata lain, empat padatan itulah yang disasar oleh pengolahan di IPAMI kawasan. Sebagai gambaran umum di bawah ini disertakan unit operasi (UO) dan unit proses (UP) yang perlu dibuat di IPAMI.

Tabel 1. Jenis unit operasi-proses dan fungsi aplikasinya dalam sistem pengolahan.

\begin{tabular}{|l|l|}
\hline \multicolumn{1}{|c|}{ Jenis UO, UP } & \multicolumn{1}{c|}{ Aplikasi } \\
\hline Preklorinasi & Oksidator Fe, Mn, pembasmi bakteri \\
\hline Pressure filter & Koloid, suspended solid \\
\hline Activated Carbon Adsorption & Bau dan rasa, pestisida, solvent, aromatics \\
\hline Mikrofiltrasi & Molekul-molekul besar, polimer \\
\hline lon Exchange & Calsium, magnesium, softening \\
\hline Reverse Osmosis & Mineral, dissolved solid \\
\hline Disinfection (UV sterilizer, O3 generator) & Pembasmi bakteri \\
\hline
\end{tabular}

Sumber: Droste, 1997, Masschelein, 1992, Verberk, Dijk, 2006. 
Tabel 2. Unit pelengkap yang mendukung sistem pengolahan.

\begin{tabular}{|l|l|}
\hline \multicolumn{1}{|c|}{ Unit Pelengkap } & \multicolumn{1}{c|}{ Fungsi } \\
\hline Ground tank, reservoir & Penampung air kiriman dari PDAM, 50 I/d. \\
\hline Oxidator tank & Oksidasi Fe, Mn, dll (dengan chlorine) \\
\hline High pressure pumps & Untuk driving force RO \\
\hline Pipa distribusi & Distribusi air layak minum, pipa PE. \\
\hline Backwash facility for filters & Suplai air pencuci, masih bisa di-reuse. \\
\hline Storage tank of potable water & Penampung air produksi IPAMI \\
\hline Faucet, kran, drinking fountain & Tapping untuk minum. \\
\hline Sludge pond & Penampung sludge rejection tahap akhir \\
\hline
\end{tabular}

\section{Preventif - Kontaminasi}

Upaya preventif sangat penting dalam instalasi potable water. Oleh sebab itu, semua pipa di instalasi, transmisi air produksi dan distribusinya tidak boleh menyebabkan pengotoran kembali (rekontaminasi) air produksi sehingga harus dihindari penggunaan pipa besi, stainless steel, dll. Upayakan memakai pipa PE atau berbahan PVC lining (bebas timbal) yang kuat terhadap beban berat. Storage tank-nya pun hendaklah berbahan PE atau yang dijamin tidak menimbulkan kikisan logam atau oksida logam.

Patut ditekankan, praolah (pretreatment) menentukan kualitas air produksi dan masa hidup (life time) membran, membran apapun yang digunakan, baik itu mikrofiltrasi, ultrafiltrasi, nanofiltrasi maupun reverse osmosis (RO). Khusus unit RO (superfiltrasi, hyperfiltrasi), kemampuannya sangat tinggi dalam meremoval ion divalen (99\%) dan 98\% untuk ion monovalen. Syaratnya, pretreatment harus tepat agar pencemar yang merusak membran seperti di bawah ini dapat disisihkan.

- scaling: $\mathrm{CaCO} 3, \mathrm{CaSO} 4, \mathrm{BaSO} 4, \mathrm{SrSO} 4, \mathrm{CaF} 2, \mathrm{SiO} 2$.

- oksida logam: oksida atau hidroksida dari Fe, Mn, Ca, Mg, Al.

- partikulat : upayakan lebih kecil daripada 5 mikron

- suspended solid: lempung dalam ukuran SS, koloid

- partikel biologis: algae, jamur, mikroba, dll.

- zat organik terlarut: pestisida, solvent, dll

- halogen: klor, kloramin, dll

Jika pretreatment tersebut tercapai, maka air produksinya akan stabil, tidak turun drastis terhadap waktu sehingga operating time-nya lama. Selain pretreatment, keberhasilan teknologi membran juga ditentukan oleh kalkulasi desain dan operasi-rawatnya. 
Sebagai gambaran, di bawah ini diberikan tiga opsi urutan pengolahan yang diperlukan dengan air umpan (feed water) dari reservoir PDAM. Apabila kualitas air kiriman PDAM tersebut memenuhi standar air umpan untuk membran dan bisa dijamin relatif stabil selama operasinya, maka unit pretreatment-nya bisa dikurangi sehingga biaya investasi, instalasi, dan O-M menjadi lebih murah.

Opsi 1 (Ion exchanger), terdiri atas (1) ground reservoir air kiriman PDAM, (2) preklorinasi, (3) oxidator tank, (4) pressure filter, (5) activated carbon adsorption, (6) ion exchanger atau zeolit softener, (7) RO system, (8) storage tank untuk potable water plus UV sterilizer, O3 generator, (9) transmisi dan distribusi (drinking fountain, dispensing faucet).

Opsi 2 (double RO system), (1) ground reservoir, (2) preklorinasi, (3) oxidator tank, (4) pressure filter, (5) activated carbon adsorption 1, (6) RO system 1, (7) activated carbon adsorption 2, (8) RO system 2, (9) storage tank untuk potable water plus UV sterilizer dan O3 generator, (10) transmisi dan distribusi (drinking fountain, dispensing faucet)

Opsi 3 (mikrofiltrasi): (1) ground reservoir, (2) preklorinasi, (3) oxidator tank. (4) pressure filter, (5) mikrofiltrasi, (6) intermediate tank (untuk split kebutuhan nonpotable water), (7) RO system, (8) storage tank untuk potable water plus UV sterilizer dan O3 generator, (9) transmisi dan distribusi (drinking fountain, dispensing faucet).

\section{Teknoekonomi}

Dari kajian di atas dapat diperoleh tiga kelompok pertimbangan teknologi membran untuk memperoleh air layak minum, yaitu:

\section{Kemampuan teknologi.}

Spektrum kemampuan teknologi membran sangat luas, dapat mengolah air berkadar garam rendah (air tawar) sampai dengan sangat tinggi, misalnya $35.000 \mathrm{mg} / \mathrm{l}$ atau bahkan $60.000 \mathrm{mg} / \mathrm{l}$. Kalau mengolah air laut saja sudah demikian mampu, maka mengolah air tawar yang sudah di-pretreatment tentu lebih mudah dan lebih murah. Itu sebabnya, selain pretreatment, keberhasilannya ditentukan juga oleh akurasi desain dan operasirawatnya yang sesuai dengan prosedur standar. 


\section{Biaya investasi (capital).}

Umumnya, makin besar kapasitas pengolahan, makin rendah biasa investasi per meter kubik air produksinya. Ini diperlihatkan oleh bentuk grafiknya yang menurun searah dengan sumbu $X$ dalam koordinat Cartesian dan sudah menjadi pengalaman atau fakta di semua unit potable water di seluruh dunia.

\section{Operasi-rawat.}

Biaya ini dipengaruhi oleh kualitas air baku, kondisi setiap unit pengolah dan harga jual airnya. Umumnya, biaya menjadi murah apabila kualitas air bakunya bagus sehingga langsung berpengaruh pada life time unit pengolah.

\section{Distillasi Sekejap Multitahap}

Sampai saat ini belum ada satu PDAM pun yang memiliki unit Distillasi Sekejap Multitahap (DSM). Dari 350-an PDAM di Indonesia, mayoritas air bakunya berasal dari mata air, sumur bor, lalu disusul air sungai. Tak ada yang menyedot air payau apalagi air laut sebagai air bakunya lantaran mahal biaya investasi dan operasi-rawatnya. Entahlah pada masa datang ketika air tawar makin sedikit dan pelanggannya terus bertambah, barangkali PDAM, terutama yang di dekat pesisir, terpaksa beralih ke teknologi desalinasi.

Dari sekian banyak teknologi desalinasi seperti elektrodialisis, mikrofiltrasi, ultrafiltrasi, nanofiltrasi, reverse osmosis dan lain-lain, teknologi DSM termasuk yang berpotensi diterapkan untuk menghasilkan air minum berbahan baku air laut dengan kapasitas besar. DSM berpeluang diterapkan oleh PDAM yang wilayahnya di tepi pantai, air tanahnya payau akibat intrusi dan sulit memperoleh air baku dari kabupaten tetangganya. Ini pun jika PDAM tak hendak menerapkan teknologi membran dengan segala kelebihan dan kekurangannya, semacam reverse osmosis.

\section{Prinsip Kerja}

DSM nyaris sama prinsip kerjanya dengan Distillasi Surya (DS) atau Solar Distillation, yaitu sama-sama membutuhkan kalor untuk evaporasi. Keduanya sama-sama proses penguapan seperti yang biasa terjadi pada pendidihan air untuk minum di rumah tangga Bedanya, kapasitas DS sangat kecil dibandingkan dengan DSM sehingga jika ditujukan untuk suplai penduduk kota, maka DSM-lah solusinya. Sebagai unit penguap, inti prosesnya adalah pendidihan air dan untuk mencapai titik didihnya itu bisa ditempuh dengan dua cara. Yang pertama, air dipanaskan atau diberi kalor sampai tercapai titik didihnya; dan yang kedua, tekanannya dikurangi (flashing). 
Konsep kedua, yaitu pengurangan tekanan itulah yang diterapkan pada unit DSM. Mengikuti hukum alam, reduksi tekanan yang diterapkan pada air mendidih menyebabkan temperatur atau titik didihnya turun. Porsi energi yang dilepaskan karena pengurangan tekanan inilah yang memasok kalor untuk menghasilkan uap. Karena garam-garamnya praktis tak bisa menguap, maka uapnya adalah murni uap air sehingga jika diembunkan akan menghasilkan air tawar, murni $\mathrm{H} 2 \mathrm{O}$ atau andaipun ada TDS-nya (total dissolved solid) konsentrasinya tak lebih dari $50 \mathrm{mg} / \mathrm{l}$.

Sebagai gambaran, konsep flashing diterapkan pada Single Flash Evaporator (Penguap atau Distillasi Sekejap Setahap), sebuah unit yang paling sederhana. Pada unit ini ruang penguapnya dianggap bertekanan satu atmosfer ( 1 bar) dan titik didih air $100{ }^{\circ} \mathrm{C}\left(212^{\circ} \mathrm{F}\right)$. Angka $250^{\circ} \mathrm{F}$ adalah temperatur uap yang ke luar dari heater, sesaat setelah dijebloskan. Dengan asumsi ini, skema prosesnya dapat dilihat pada gambar 1. Pada gambar tersebut ada tiga ruang (kamar, chamber), tapi pada unit sederhana hanya ada satu ruang, yaitu ruang yang paling kanan dan pemanasnya (heater). Pada tabel 1 ditunjukkan bahwa unit sederhana ini tidak efisien sehingga yang dibangun adalah unit ganda atau multitahap.

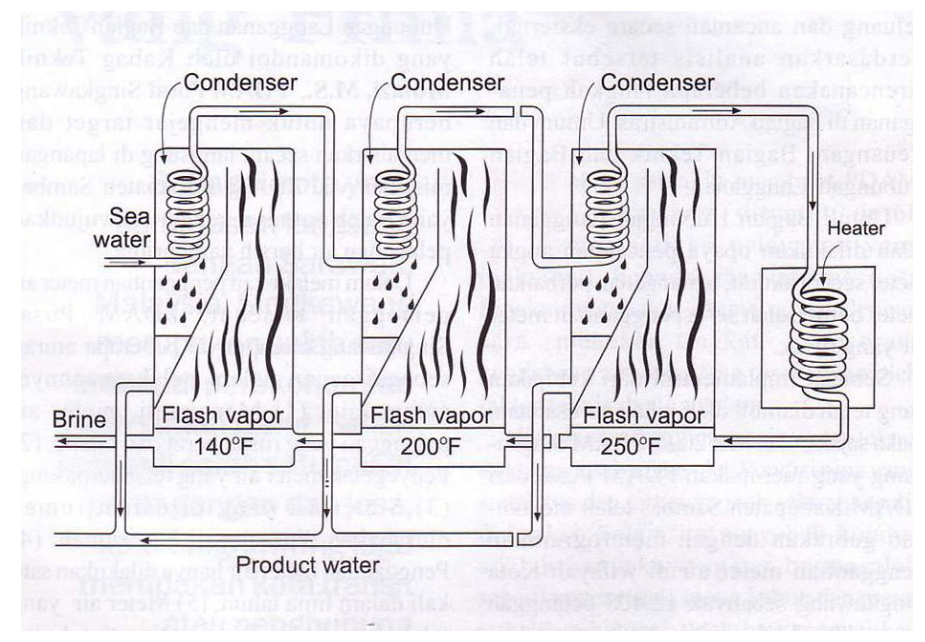

Gambar 1. Distillasi Sekejap Multitahap

Air laut dipanaskan sampai temperatur $120^{\circ} \mathrm{C}\left(250{ }^{\circ} \mathrm{F}\right)$, tekanan 2 bar, lalu dijebloskan ke ruang penguap bertekanan 1 bar. Karena titik didih pada tekanan 1 bar adalah $100{ }^{\circ} \mathrm{C}$, maka secara mendadak air melepaskan uap sehingga temperaturnya turun. Uapnya ke atas, masuk ke ruang kondensasi (pengembunan) lalu mencair menjadi air tawar. Pengembunan itu justru dibantu oleh air laut umpan sebagai media pendingin (kondesor) yang otomatis hemat energi sebab dapat mereduksi jumlah kalor yang harus dipasok ke dalam pemanas. Demi mengurangi kebutuhan pasokan kalor pada pemanas, air laut 
umpan yang akan masuk ke ruang pengembun terlebih dulu dihangatkan oleh air asin panas yang ke luar dari kamar penguap.

Efisiensi biasanya dinyatakan dalam volume air tawar produksi per satu satuan kalor yang dipasok pada pemanas. Lantaran medium pemanasnya berupa steam (kukus), lazimlah efisiensinya dinyatakan dalam ton air tawar yang dihasilkan per ton kukus yang dikonsumsi. Karena kalor penguapan air laut kira-kira sama dengan kalor pengembunan kukus, maka pada distillasi satu tahap yang sudah dioptimalkan pun nilai efisiensi maksimalnya tetap saja satu. Ini tentu tidak menggembirakan sebab ongkos produksi kukusnya menjadi porsi terbesar dari harga air tawar yang dihasilkan. Bagaimana solusinya?

\section{Kinerja DSM}

Solusinya adalah serial unit atau multistage sehingga disebut Multistage Flash Evaporator. Unit ganda berurutan multitahap ini bisa dideretkan menjadi $\mathrm{n}$ tahap dan nilainya berkisar antara 15 - 60. Sebagai ilustrasi, pada Gambar 1 diberikan contoh unit tiga tahap yang bisa mewakili multitahap karena sama prinsip kerjanya.

Air laut yang sudah dipanaskan dialirkan melewati kamar-kamar penguap (atau tahaptahap penguapan sekejap). Setiap kamar beroperasi pada tekanan yang lebih rendah daripada kamar di hulunya sehingga temperatur didih airnya juga lebih rendah. Akibatnya, air asin yang keluar dari tahap akhir akan bertemperatur paling rendah sehingga tak membawa banyak energi yang terbuang sia-sia. Juga tak selamanya air laut yang hangat ini dibuang seluruhnya. Ada sebagian yang dicampurkan lagi ke dalam air laut segar umpan proses sehingga terdaur ulang dan energinya yang tersisa masih bisa dimanfaatkan.

Tekanan dan temperatur operasi terendah pada tahap akhir DSM ini ditetapkan berdasarkan pertimbangan volume uap (volume per satuan massa uap membesar jika tekanannya makin rendah) dan kelancaran perpindahan kalor di kondensornya. Rentang umum temperaturnya adalah $37-40{ }^{\circ} \mathrm{C}$ pada tekanan operasi $0,06-0,07$ bar. Tekanan tahap-tahap yang beroperasi pada kondisi vakum (temperatur operasinya kurang dari 100 ${ }^{\circ} \mathrm{C}$ ) dipertahankan dengan isapan penghampa (pada gambar 1 tidak tampak). Temperatur tertinggi yang bisa diterapkan pada air laut yang keluar dari pemanas biasanya dibatasi pada $120^{\circ} \mathrm{C}\left(250{ }^{\circ} \mathrm{F}\right)$ untuk mengendalikan kerak (scaling) kalsium karbonat (CaCO3) dan magnesium hidroksida $\mathrm{Mg}(\mathrm{OH}) 2$ pada pipa. 
Secara umum efisiensi DSM membesar jika jumlah unitnya $(n)$ makin banyak seperti diperlihatkan pada Tabel 3. Tampak efisiensi atau nisbah kerja unit ke-43 sampai unit ke60 tak terlalu jauh bedanya. Yang satu bernisbah 10, yang satunya lagi 11. Bedanya hanya satu dan ini pertanda bahwa unitnya sudah jenuh alias capek. Lebih dari 60 kamar akan terus menurun dan makin tidak efisien.

Tabel 3. Korelasi $\mathrm{n}$ terhadap nisbah kinerja (efisiensi)

\begin{tabular}{|c|c|}
\hline Jumlah chamber, $\mathrm{n}$ & nisbah kinerja, ton per ton \\
\hline 1 & $\approx 1$ \\
\hline 19 & 5,5 \\
\hline 31 & 8 \\
\hline 43 & 10 \\
\hline 60 & 11 \\
\hline
\end{tabular}

DSM, seperti ditulis pada awal artikel ini, adalah desalinator yang kompetitif dan sudah banyak diterapkan. Saat ini diperkirakan $65 \%$ air desalinasi di seluruh dunia diperoleh dari DSM. Hanya saja, demi efisiensi, perlu ada perbaikan kinerja, misalnya digabung dengan unit reverse osmosis dan pembangkit listrik tenaga uap, baik berbahan bakar batubara, gas, maupun BBM. Bahan bakar dari sampah pun boleh-boleh saja asalkan memang layak diinsinerasi. Itu sebabnya, implementasi pembangkit listrik-DSM-RO (tiga unit yang digabung) atau menjadi empat unit (insinerator-pembangkit-DSM-RO) perlu mempertimbangkan capital recovery costs, fuel costs, dan operation-maintenance costs secara total dengan analisis SWOT (strength, weakness, opportunity, threat) di daerah masing-masing. Jika demikian, kapan PDAM yang daerahnya di dekat laut menerapkan DSM?

\section{Penutup}

Teknologi desalinasi, baik yang menerapkan teknologi membran maupun yang penguapan, menjadi peluang yang menjanjikan pada masa yang akan datang, khususnya di daerah yang dekat laut tetapi sulit air tawar. Selain diterapkan untuk desalinasi, teknologi membran pun dapat digunakan untuk memperoleh air yang siap diminum seperti kawasan terbatas (permukiman, hotel, kampus, dll). Hanya saja, kendala utama penerapannya adalah pada masalah biaya, baik investasinya maupun operasi-rawatnya. * 


\section{Daftar Pustaka}

1. Droste, Ronald. L, Theory and Practice of Water \& Wastewater Treatment, John Wiley \& Sons. Inc, 1997.

2. Heitmann, Hans G., Saline Water Processing, VHC, 1990.

3. Masschelein, Willy J., Unit Processes in Drinking Water Treatment, Marcel Dekker, Inc. New York, 1992.

4. Moel, Verberk, Dijk., Drinking Water, World Scientific., 2006.

5. Mulder Marcel, Basic Principles of Membrane Technology, Kluwer A. P., 1996

6. AWWA, Water Treatment Plant Design, McGraw-Hill, Inc., 1990.

Dipublikasikan di Jurnal Sosioteknologi Terapan, Volume XIV, hlm. 45-56, Bulan Februari 2010, ISBN 978-979-17974-4-3 